\title{
The Role of Mycoplasma Membrane Proteins in the Adsorption of Animal Cells to Mycoplasma hominis Colonies
}

\author{
By M. R. HOLLINGDALE. \\ Department of Microbiology, Lister Institute of Preventive Medicine, \\ Chelsea Bridge Road, London, SWI W8RH \\ AND R. J. MANCHEE \\ M.R.C. Clinical Research Centre, Harvard Hospital, Salisbury, Wiltshire \\ (Accepted for publication I6 November I97I)
}

Colonies of Mycoplasma pneumoniae and Mycoplasma gallisepticum adsorb many types of animal cell, including erythrocytes of various species, spermatozoa and tissue culture cells (Manchee \& Taylor-Robinson, 1969). This adsorption can be prevented by treating the colonies with antiserum to whole mycoplasma organisms. The adsorption-inhibiting activity of the serum can in turn be abolished by treating the serum with haptens isolated from mycoplasmas. We have examined the role of specific mycoplasma antigens, particularly those of the cell membrane, in the adsorption of $\mathrm{H}$-HeLa cells to colonies of a strain of Mycoplasma hominis.

\section{METHODS}

Mycoplasma hominis, $\mathrm{SC} 4$, isolated from the urethra of a man attending a venereal diseases clinic, was used throughout. Antisera to whole organisms, purified membranes and soluble fraction were those prepared by Hollingdale \& Lemcke (I969). Antisera to lipid-free and recombined membranes and urea extract of whole membranes were prepared in rabbits according to Hollingdale \& Lemcke (1972).

In the test for inhibition of $\mathrm{H}-\mathrm{HeLa}$ cell adsorption, the culture medium, growth of mycoplasma colonies on agar and origin of $\mathrm{H}-\mathrm{HeLa}$ cells were as described by Manchee \& Taylor-Robinson (1969). Suitable colonies of the mycoplasma, preferably in groups of three or four, were surrounded with a glazed porcelain assay cylinder; about six cylinders were used on each agar plate. Each cylinder was filled with a dilution of the antiserum, prepared by a twofold serial dilution in $20 \%(\mathrm{v} / \mathrm{v})$ normal guinea-pig serum in phosphatebuffered saline $\mathrm{pH} 7 \cdot 2$. Control cylinders contained $20 \%(\mathrm{v} / \mathrm{v})$ normal guinea-pig serum in phosphate-buffered saline alone. After the plates had been incubated at $37^{\circ}$ for $3 \mathrm{~h}$, the antiserum was replaced with $\mathrm{H}-\mathrm{HeLa}$ cell suspension in phosphate-buffered saline $\left(2 \times 10^{6}\right.$ cells/ $\mathrm{ml}$ ) and the plates reincubated at $37^{\circ}$ for $2 \mathrm{~h}$. The cylinders were emptied and removed, excess cell suspension removed with a few $\mathrm{ml}$ phosphate buffered saline and the colonies examined under a stereo-plate microscope. The adsorption-inhibition titre was taken as the reciprocal of the dilution of antiserum which reduced cell adsorption to $25 \%$ compared with untreated control colonies. The method for metabolic inhibition was as described by Hollingdale \& Lemcke (1969). The metabolic inhibition titre was the highest dilution of antiserum inhibiting a colour change of $0.5 \mathrm{pH}$. 


\section{RESULTS}

The effect of whole organisms and fractions of Mycoplasma hominis on the adsorptioninhibition and metabolic-inhibition titres of homologous antiserum is shown in Table I. Metabolic-inhibition titres were included because the corresponding antigens are located on the membrane (Hollingdale \& Lemcke, 1969). Antiserum to whole organisms inhibited cell adsorption, although titres were appreciably lower than those of the metabolic-inhibiting antibody. Whole organisms or membranes, prepared according to Hollingdale \& Lemcke (1969), removed most of the adsorption-inhibiting activity as well as metabolic-inhibiting antibody. In contrast, the soluble fraction had little effect on either antibody. Similarly, antiserum against membranes purified on sucrose density gradients (Hollingdale \& Lemcke, I969) also inhibited cell adsorption, whereas antiserum against the soluble fraction did not (Table I). Thus, antibodies responsible for inhibiting adsorption of $\mathrm{H}-\mathrm{HeLa}$ cells, like those active in causing metabolic inhibition, are directed against the mycoplasma cell membrane.

With antisera to lipid-free membranes and the same membranes recombined with the lipid extracted by $n$-butanol from whole membranes (prepared according to Rodwell, Razin, Rottem \& Argaman, 1967), the adsorption-inhibition titres were very similar, and were of the same order as those of antisera against purified membranes or whole organisms (Table I).

As proteins rather than lipids are important in the interaction of Mycoplasma hominis membranes with $\mathrm{H}-\mathrm{HeLa}$ cells, two extracts prepared by methods known to bring proteins into solution (namely cold aqueous phenol or $8 \mathrm{M}$ urea: Hollingdale \& Lemcke, 1969; 1972) were tested for their ability to adsorb antibody from antiserum to whole organisms. Each extract lowered the titre fourfold in adsorption-inhibition tests and 16 to 32 in the metabolicinhibition test: in neither test did the extracts remove all activity. Antiserum to the urea extract did not block H-HeLa cell adsorption, although it showed weak metabolic inhibition (Table I).

Table I. Inhibition of $\mathrm{H}-\mathrm{HeLa}$ cell adsorption, and metabolism by antisera to fractions and extracts of Mycoplasma hominis SC4

\begin{tabular}{lrr} 
& \multicolumn{2}{c}{ Inhibition titre for } \\
\cline { 2 - 3 } $\begin{array}{c}\text { Cell } \\
\text { adsorption }\end{array}$ & Metabolism \\
Antiserum against & & \\
Whole organisms & 80 & 2560 \\
Purified membranes & 40 & I60 \\
Soluble fraction & $<\mathrm{IO}$ & $<10$ \\
Lipid-free membranes & 40 & 160 \\
Recombined membranes & 40 & 320 \\
Urea extract & $<10$ & 40 \\
& & \\
Antiserum, against whole & & \\
organisms, absorbed by & & 2560 \\
Nil & 160 & 1280 \\
Phosphate-buffered saline & 80 & $<10$ \\
Whole organisms & $<10$ & 10 \\
Crude membranes & $<10$ & 1280 \\
Soluble fraction & 80 & 80 \\
Urea extract & 40 & \\
Phenol extract & 40 &
\end{tabular}




\section{DISCUSSION}

These results support the suggestion of Manchee \& Taylor-Robinson (1969) that protein receptors in the membrane of Mycoplasma hominis are involved in the adsorption of $\mathrm{H}$ HeLa cells. Nevertheless, the proteins extracted with urea or phenol did not absorb all of the adsorption-inhibiting antibody from antiserum to whole organisms, possibly due to the absence of certain antigens, which gel-diffusion tests failed to demonstrate, although they were present in preparations of whole membranes lysed with detergent (M. R. Hollingdale \& R. M. Lemcke, unpublished observations). The failure to abolish the metabolic-inhibition reaction completely may have the same cause. The greater sensitivity of the metabolicinhibition tests probably accounts for the fact that the metabolic-inhibiting antibody, but not adsorption-inhibiting antibody, was detected in antiserum to the urea extract.

That the proteins rather than the lipids of Mycoplasma hominis membranes are concerned in H-HeLa cell adsorption contrasts with the results of Sobeslavský, Prescott \& Chanock (I968) with Mycoplasma pneumoniae. Here, inhibition by antiserum was blocked by lipids but not by proteins or polysaccharides of the organism. Moreover, the lipid hapten of $M$. pneumoniae was also active in tests for complement-fixation, and precipitin and in blocking metabolic-inhibition and indirect-haemagglutinating antibody, whereas lipid extracts from $M$. hominis were virtually inactive in these tests (Hollingdale \& Lemcke, 1969). Mycoplasma hominis also differs from Mycoplasma mycoides var mycoides in that it contains no serologically reactive polysaccharide (Hollingdale \& Lemcke, 1969).

Thus, the soluble and membrane antigens determining the serological activity of mycoplasmas differ substantially in their chemical nature from species to species. The same diversity may evidently prove to be true of the receptors associated with cell adsorption.

We thank Drs R. M. Lemcke and D. Taylor-Robinson for their helpful advice, and the Medical Research Council which provided the remuneration of M.R.H.

\section{REFERENCES}

Hollingdale, M. R. \& Lemcke, R. M. (1969). The antigens of Mycoplasma hominis. Journal of Hygiene $67,585-702$.

Hollingdale, M. R. \& Lemcke, R. M. (1972). Membrane antigens of Mycoplasma hominis. Journal of Hygiene (In the press).

MANCHEe, R. J. \& TAYlor-Robinson, D. (I969). Studies on the nature of receptors involved in the attachment of tissue culture cells to mycoplasmas. British Journal of Experimental Pathology 50, 66-75.

Rodwell, A. W., Razin, S., Rottem, S. \& Argaman, N. (1967). Association of protein and lipid in Mycoplasma laidlawii membranes disaggregated by detergents. Archives of Biochemistry and Biophysics $\mathbf{1 2 2}$, $621-628$.

Sǒbeslavský, O., Prescott, B. \& Chanock, R. M. (I968). Adsorption of Mycoplasma pneumoniae to neuraminic acid receptors of various cells and possible role in virulence. Journal of Bacteriology 96, 695-705. 